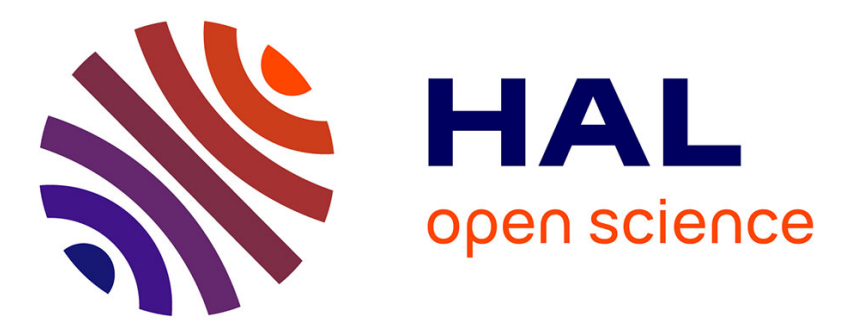

\title{
Impacts of salespeople's biased and unbiased performance attributions on job satisfaction : the concept of misattributed satisfaction
}

Christine Jaushyuam Lai-Bennejean, Lauren Beitelspacher, Christine Lai-Bennejean

\section{To cite this version:}

Christine Jaushyuam Lai-Bennejean, Lauren Beitelspacher, Christine Lai-Bennejean. Impacts of salespeople's biased and unbiased performance attributions on job satisfaction: the concept of misattributed satisfaction. European Journal of Marketing, 2020, FORTH. hal-02902741

\section{HAL Id: hal-02902741 \\ https://hal.science/hal-02902741}

Submitted on 25 Oct 2021

HAL is a multi-disciplinary open access archive for the deposit and dissemination of scientific research documents, whether they are published or not. The documents may come from teaching and research institutions in France or abroad, or from public or private research centers.
L'archive ouverte pluridisciplinaire HAL, est destinée au dépôt et à la diffusion de documents scientifiques de niveau recherche, publiés ou non, émanant des établissements d'enseignement et de recherche français ou étrangers, des laboratoires publics ou privés. 


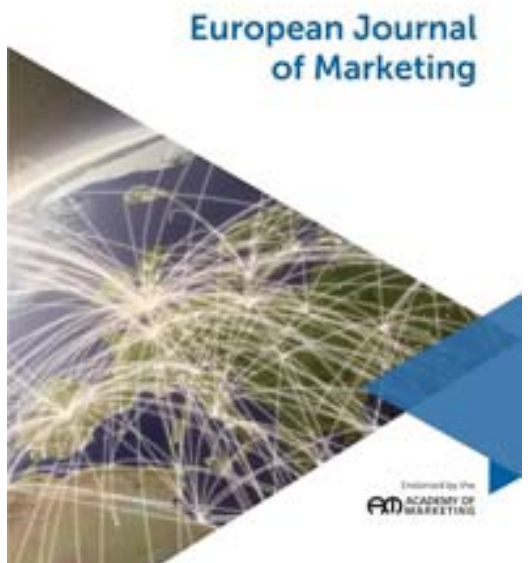

I mpacts of salespeople's biased and unbiased performance attributions on job satisfaction: the concept of misattributed satisfaction

Christine Lai-Bennejean, Department of Marketing, Emlyon Business School, Ecully, France, and Lauren Beitelspacher, Department of Marketing, Babson College, Wellesley, Massachusetts, USA

\begin{tabular}{|r|l|}
\hline Journal: & European Journal of Marketing \\
\hline Manuscript ID & EJ M-11-2018-0816.R2 \\
\hline Manuscript Type: & Original Article \\
\hline Keywords: & J ob satisfaction, Sales, Sales performance, Sales force, causal attribution \\
\hline \multicolumn{2}{|l}{} \\
\hline
\end{tabular}

\section{SCHOLARONE $^{\text {m }}$}

Manuscripts 


\title{
Impacts of salespeople's biased and unbiased performance attributions on job satisfaction: the concept of misattributed satisfaction
}

\begin{abstract}
Purpose - This article investigates an under-researched area, the impact of causal attributions (i.e., causal stability and company-related/-unrelated attributions) on salespeople's job satisfaction following their performance appraisal.

Design/methodology/approach - A pretest and a between-subjects experimental study test the effect of accurate or biased perceptions of causal attributions on salespeople's job satisfaction. Data collected from 209 salespeople provide evidence that they make perceptual attribution errors in their appraisals of the performance outcome they achieve or do not achieve.

Findings - When salespeople correctly attribute their performance, causal stability affects their job satisfaction. However, company-related attributions affect their satisfaction only in the case of a poor performance outcome. As expected, salespeople who make biased attributions experience misattributed or "unwarranted" satisfaction or dissatisfaction, a higher or lower satisfaction level than they would have experienced had they made proper causal attributions.
\end{abstract}

Practical implications - This study discusses how managers can ensure continued satisfaction of their salespeople, which constitutes a stable source of motivation, by understanding their performance attributions.

Originality/value - This research introduces a new concept of misattributed job satisfaction or dissatisfaction. While anecdotally some scholars have investigated when salespeople play "the blame game," this research shows how salespeople correctly or incorrectly ascribe blame for the outcomes and the impact on job satisfaction.

Keywords Sales force management, Job satisfaction, Causal stability, Company-related attribution, Experimental study

Paper type Research paper 


\section{Introduction}

Determining the antecedents of employee job satisfaction alludes many organizations. Managers who supervise salespeople and other frontline employees are particularly concerned about job satisfaction, because it leads to increased customer satisfaction (Zablah et al., 2016), organizational commitment (Marshall et al., 2012), and decreased intentions to leave (Wang and Ma, 2013). Furthermore, boundary-spanning employees' dissatisfaction may cause considerable losses. If dissatisfied salespeople leave, the associated costs with recruiting, training, and the retention of organizational knowledge all rise. Conversely, if they choose to stay, they may fail to provide adequate service going forward (Lai and Gelb, 2019).

A common way for managers to enhance sales force satisfaction is by providing effective support and satisfactory compensation plans (e.g., Chung, 2015; Shipley and Kiely 1988; Steenburgh and Ahearne, 2012). In line with cognitive judgement approaches, these actions indicate that job satisfaction, a necessary source of work motivation, can be improved through a set of concrete or abstract work features that match or exceed employees' perceived standards (Locke and Latham, 2004; Weiss and Cropanzano, 1996). However, in this cognitive appraisal process, managers often overlook a key contributor to sales force satisfaction—salespeople's performance attributions.

Job satisfaction is an emotional response to the appraisal of one's job or job experience (Locke 1976). It forms through a process of evaluation between what is attained and what was expected.

During the process of assessement, people instinctively attempt to understand the causes of the achievement or underachievement (Heider 1958). It therefore seems reasonable to pursue the idea that performance attributions cause job satisfaction. Research acknowledges that a salesperson's performance attribution can have a motivational impact on his or her effort in the future (e.g., Dixon $e t$ al., 2001). However, it has not thoroughly investigated the attributional causal effect on sales force satisfaction (Johnson, 2006). 
According to Weiner's $(1985,2014)$ attribution-emotion theory, individual affective reactions are associated not only with the outcome of goal attainment but also with the individual's perceptions of the causes of these outcomes. Salespeople who do not achieve their goals might have lower levels of satisfaction when they attribute that outcome to limited company support or access to resources than those attributing the same outcome to environmental forces beyond the company's control. This paper adopts Weiner's attribution-emotion theory as a theoretical lens to investigate the causal linkage between salespeople's performance attributions and their job satisfaction. Specifically, it investigates the effects of two attributional dimensions (stable/unstable and company-related/-unrelated) on a salesperson's job satisfaction following his or her performance appraisal. In sales literature, most studies view the salesperson as an actor whose attributions (either internal or external) lie within his or her control (see Table I). By contrast, this study focuses on the salesperson's perception that performance outcomes are due to factors for which "the company" (the actor) is responsible or over which the company has control (Nishi et al., 2008). Examining this dimension in salespeople's causal attribution process is important because it indicates salespeople's assignment of responsibility to the firm for the obtained outcome, which results in their satisfaction. If the causal attribution is correct, managers should take every possible step to re-establish satisfaction, especially in the case of poor performance outcomes.

The performance outcomes salespeople achieve are often associated with the success of company-related (non-sales-force) activities, such as the company's advertising campaigns and promotional activities (Seriki et al., 2016). In this shared sales cycle, when salespeople believe that non-sales-force efforts are responsible for their under-performance, this causal attribution may lead to job dissatisfaction (blaming effect). This dissatisfaction may be greater if they believe that the ineffectiveness of such firm initiatives will continue in the future (stable over time). Conversely, salespeople may believe that they achieved quota because sales promotions took place in their territory 
in a timely fashion. Yet if they believe that this effect is only temporary (variable over time), they are likely to experience lower satisfaction than those who believe this effect will remain.

More important, attribution errors are likely to occur when an individual assesses the situation and makes causal inferences of the outcome (Tetlock and Levi, 1982). Such biases that misrepresent the actual cause may shape salespeople's affective responses to their work environment. Understanding salespeople's causal analysis following their performance appraisals is important because this cognitive appreciation of their work environment, including achievement-related features, with or without bias, is a proximal cause of their job satisfaction. The impact of biased and unbiased causal attributions on sales force satisfaction is under-researched in sales literature.

The goals of this paper are twofold: (1) to investigate how the two properties of causal attributions (i.e., stable/unstable and company-related/-unrelated) influence a salesperson's job satisfaction following performance appraisal and (2) to test the effect of biased or unbiased perceptions of respective causal attributions on job satisfaction. Thus, the study uses a between-subjects experimental design with 209 salespeople to test the causality between performance attributions and job satisfaction. The results show that salespeople's unbiased perceptions of the two properties of causal attributions exert distinct influences on job satisfaction. Furthermore, the results show that salespeople still make attribution errors of assigning a true cause of the given situation when the conditions are made clear to them. Such biased attributions result in inflated or deflated satisfaction, a misattributed satisfaction that is higher or lower than the salespeople would have experienced had they made proper causal attributions. This study provides insights into the underlying attributionsatisfaction mechanisms following salespeople's performance appraisals. The anticipation of this attribution process is important for corrective measures. Understanding salespeople's causal analysis following their achievements can help managers enhance sales force satisfaction by indicating true 
causes when attribution is correct. Managers' involvement in salespeople's attribution process shapes their attitudinal and behavioural reactions. Communicating the true cause results in beneficial effects by leading salespeople to revise wrong attributions, which in turn can help secure a stable source of satisfaction.

The next section provides a literature review of the salesperson attribution-satisfaction relationship. Next, the conceptual framework is presented along with research hypotheses and the empirical study. The paper concludes with a discussion of the findings, theoretical and managerial implications, and the study's limitations.

\section{Theoretical background}

In general, sales researchers agree that salespeople's perceptions of performance appraisals are likely to precede their attitudes and behaviours in the causal chain. Table I summarises empirical studies that examine the linkage between salespeople's performance attributions and their attitudinal and behavioural reactions and suggests three conclusions. First, one stream of research explores how personal characteristics (e.g., individual culture) and organizational factors (e.g., control system) lead to salespeople's causal attributions, which in turn impact their behavioural intentions (e.g., effort estimates) or attitudes (e.g., satisfaction). Second, research categorises performance attributions in three ways - locus of causality, causal stability, and controllability — indicating that attributions lie within a salesperson's control. The actor of the behaviour or in the event is the salesperson. However, there are usually more than one causal agents (e.g., salesperson, manager, firm) in the chain following sales performance, a notion that has not been thoroughly investigated. The linkages between the causes and the consequences may depend on the categories of the causes (Folkes, 1988). Third, another stream of research suggests that individuals explain causal inferences following events in a systematic and relatively stable way, which indicates an attributional style. The associations between individual 
salespeople's attributional styles and their attitudinal and behavioural reactions are examined (e.g., job satisfaction and effort).

Table I here

By investigating how salespeople's attributions following their performance appraisals, with or without bias, impact their job satisfaction, this study contributes to extant literature in two ways. First, in contrast with most studies focusing on salesperson-related attributions, this research investigates the causal factors the company is responsible for and examines the associations between company-related/unrelated attributions and sales force satisfaction. Salespeople may respond attitudinally depending on the attributions they make about the company's purpose and ability to implement the relevant practices. However, little is known about salespeople's reactions to the attributions they make about the activities for which the company is responsible. By investigating this causal process, managers may know when to take remedial actions directly.

Second, the causal chain may be more complex than what previous research has found. Cognitive biases or distortions may occur in people's appraisal of the situation, such that they over-estimate or disregard the causal effect of a personal or environmental factor (Ross, 1977). In the cognitive judgement process, biases are a regular by-product when people follow the general principles of judgements and can be the result of cognitive limitations, intuitive judgements, an egocentric perspective, or specific motivations (Keren and Teigen, 2004). In particular, biases are frequently discussed within the framework of attributional theory, such as motivational biases (also called "selfserving biases") and perceptual biases (also called "correspondence bias" and "fundamental attribution error") (Huber et al., 1986; Malle, 1999). The former indicates that observers have a tendency to attribute success to internal causes to enhance self-esteem while attributing failure to external causes to protect their ego (Tetlock and Levi, 1982). The latter refers to a tendency of observers (here, salespeople) to attribute the actor's (here, the company's) behaviour or action to its associated qualities 
rather than the situational factors. This study focuses on the effect of a perceptual bias of two properties (i.e., causal stability and company-related/-unrelated attributions) rather than self-serving bias observed only in self-related attributions.

\section{Conceptual model and hypotheses}

Weiner's (1985) theory provides the theoretical basis for this study. This theory explores attributions that people make within domain-specific contexts, such as achievement and helping (Hewett et al., 2018). In addition, the theory explains how causal attributions influence individuals' future expectations, emotions, and performance (Reisenzein, 2014; Weiner, 2014). According to the theory, following the outcome of an event, a person may experience a general positive or negative affective reaction depending on his or her primary appraisal of the perceived success or failure of the event. For example, a salesperson who meets sales quota may feel happy but feel frustrated if the quota is not met. After the outcome appraisal, the person may experience a different set of emotions due to the causal inferences for the outcome. In this example, meeting a sales quota as a result of an efficient sales promotion would likely generate more positive feelings than meeting the quota following a series of product recalls from a competitor.

People implicitly appraise everything they are confronted with, and their evaluations of these appraisals, in turn, shape their affective reactions (Clore and Ortony, 2008). Acknowledgement of work outcomes frequently serves as a primary cue eliciting a salesperson's attribution process for searching for post hoc explanations (Teas and McElroy, 1986). The salesperson's appraisal of this job experience results in a pleasurable or positive emotional state, namely job satisfaction (Locke, 1976).

Figure 1 outlines how a salesperson's biased or unbiased attributions following a performance appraisal may affect his or her job satisfaction. Specifically, it addresses the effects of accurate or biased perceptions of two major properties of attributions (stable/unstable and company-related/unrelated) on job satisfaction. Table II defines the constructs of this study. 
Figure 1 and Table II here

\section{Primary performance appraisal and job satisfaction}

In general, salespeople are assigned sales objectives related to their expected performance (e.g., quotas), and frequently they experience a gap between their expected and actual performance (Bridges et al., 2007). Conceivably, salespeople's perceptions of this gap (i.e., performance appraisals) may influence their job satisfaction (Pettijohn et al., 2001). This is in line with Weiner's (1985) theory that a person's primary appraisal of an event (success or failure) gives rise to a general positive or negative affective reaction. Research widely acknowledges that a person's job satisfaction depends on the attainment or non-attainment of personal objectives (Weiss et al., 1999). However, the current research examines job satisfaction as a reflection not only of goal attainment but also of the salesperson's appraisals and attributions. To do so, the model must be grounded in the notion that personal goal attainment is related to job satisfaction. Thus:

H1. Salespeople's attainment of their objectives is positively related to their job satisfaction.

\section{Causal attributions and job satisfaction}

In addition to the affective reactions caused by the primary appraisal of the outcome of an event (attainment or non-attainment of the goal), how the salesperson explains such outcomes, with or without bias, may also influence his or her job satisfaction. This study focuses on the effects of two causal dimensions on salesperson job satisfaction: stable/unstable causes and company-related/unrelated causes. It first presents hypotheses about how attributional dimensions, without bias, may have distinct effects on salesperson job satisfaction.

Stability. According to Weiner's (1985) theory, the outcome's cause that the salesperson identifies can be evaluated on its stability: the extent to which the cause is expected to endure versus fluctuate. A stable cause (e.g., company's reputation) remains fairly consistent over time, whereas an 
unstable cause (e.g., sales promotion) is subject to change under temporal conditions. Weiner delineated that the stability of a cause determines a person's expectation of future success. If the presence or absence of a cause is expected to remain, the outcome experienced (success or failure) will be expected to recur. This continued expectancy influences a person's assessment of the work environment, which in turn shapes his or her job satisfaction (Locke, 1976). For example, when a salesperson ascribes a positive outcome to a stable cause, he or she will perceive an increasing linkage between sales inputs and performance (Johnston and Kim, 1994). The perceived advantage provided by a stable cause will not change, and consequently the salesperson will expect the positive outcome to return and likely experience higher job satisfaction than if he or she attributed the same outcome to an unstable cause. Conversely, when attributing a negative outcome to a stable cause, salespeople are likely to have lower job satisfaction than when the outcome is attributed to an unstable cause. Thus:

$H 2 a$. When actual performance is greater than expected, salespeople who correctly (without bias) attribute the positive outcome to stable causes experience higher job satisfaction than those attributing the outcome to unstable causes.

$H 2 b$. When actual performance is lower than expected, salespeople who correctly (without bias) attribute the negative outcome to stable causes experience lower job satisfaction than those attributing the outcome to unstable causes.

Company-related/-unrelated causes. As previously discussed, this study focuses on salespeople's perceptions that performance outcomes are due to the causes for which the company is responsible or over which it has control. Attributions that lie within the company's control are not a novel causal dimension in human resources (HR) research (Hewett et al., 2018). Considering HR practices, it is expected that salespeople respond attitudinally depending on the attributions they make about the company's responsibility and the motives underlying the business practices they experience. A company-related cause refers to factors over which the company has control, while a company- 
unrelated cause refers to factors beyond the company's control; in the latter case, the company is perceived as a passive recipient of environmental forces (Nishii et al., 2008). For example, low product sales can be due to non-sales-force factors that are firm controllable (e.g., product quality) or environment related (e.g., customers' changing habits).

Company-related causes have direct relevance to job satisfaction because they are tied to salespeople's appreciation for or blame of the firm's responsibilities. When a negative outcome occurs, the cause internal to the manager or controllable by the company will lead to negative employee attitudinal and behavioural reactions (e.g., anger, fear, withdrawal) (Tomlinson and Carnes, 2015). Similarly, salespeople's perceptions of the firm's marketing efforts influence their capacity to perform their jobs successfully, which in turn may lead to satisfaction (Allison et al., 2016). Thus, when salespeople attribute a positive outcome to a company-related cause, they will be pleased with the firm's effort and likely have higher job satisfaction than salespeople attributing the same outcome to a company-unrelated cause. Conversely, when attributing a negative outcome to a company-related cause, salespeople may blame the company for being responsible for the sales failure and likely experience lower job satisfaction than salespeople attributing the same outcome to a companyunrelated cause. Thus:

$H 3 a$. When actual performance is greater than expected, salespeople who correctly (without bias) attribute the positive outcome to company-related causes experience higher job satisfaction than those attributing the outcome to company-unrelated causes.

$H 3 b$. When actual performance is lower than expected, salespeople who correctly (without bias) attribute the negative outcome to company-related causes experience lower job satisfaction than those attributing the outcome to company-unrelated causes.

\section{Effect of attribution bias}


A perceptual bias is an automatic outcome of people's perceptual experiences (McArthur and Baron, 1983). Salespeople first identify informational cues from the company's immediate behaviour, the situation, and any other information they may have about the actor. They then use these identifications as data for the inference. They may assess the likely causes of an event by the degree to which the event is readily accessible in memory. Instead of processing the situational cues, they may intuitively select data and make attributions depending on the ease with which they can remember instances of similar events (Bazerman and Moore, 2009).

In addition to cognitive limitations, Langdridge and Butt (2004) specify that attribution bias arises when the observer fails to discern a series of meaningful actions on the actor's part and attributes intentionality to the actor rather than responding to the situational cues. The success of non-sales functions the company is responsible for has an effect on salespeople's performance. When salespeople are engaged in their work, the company's actions become dominant in their perceptions. Accordingly, they may under-estimate the effect of the situation. Thus, attribution bias arises in the performance attribution process when salespeople quickly and reflectively read the company's intentions and are less concerned about the situational factors. This inaccuracy or distortion in judgement leads salespeople to misinterpret events and, thus, to adopt exaggerated or unusual attitudes and behave in ways that are maladaptive (Ross, 1977).

Though the boundary-spanning positions enable salespeople to gain access to information, they do not necessarily have an overall view of how relevant sales and non-sales functions are casually associated in the sales system. Relying on intuitively selected data or information readily accessible, they are likely to incorrectly attribute a positive outcome to a stable cause (e.g., product innovation) and believe that this positive outcome will continue in the near future. However, when the "correct" cause is actually temporary (e.g., sales promotion), they are likely to experience higher job satisfaction than those with correct attributions. Similarly, salespeople who incorrectly attribute a negative outcome 
to a stable cause may experience lower satisfaction than those with correct attributions, when the "correct" cause is temporary.

Furthermore, when facing a positive (or negative) outcome, salespeople may incorrectly attribute it to a company-related cause (e.g., company's reputation) depending on their beliefs in the company's ability and intention, but if the "correct" cause is company-unrelated (e.g., product recalls from a competitor), they are likely to experience higher (or lower) job satisfaction than those with correct attributions. Thus, biased causal attributions are likely to result in inflated or deflated satisfaction - that is, higher or lower satisfaction than salespeople would have experienced had they made proper attributions. Here, this inflated or deflated satisfaction is defined as "misattributed satisfaction." Misattributed satisfaction means that the satisfaction resulting from inaccurate attributions is unjustified because the satisfaction is derived erroneously. In addition, misattributed satisfaction is temporary because it can change when biased attributions are corrected or altered. Thus:

H4. When actual performance is greater than expected, (a) salespeople who incorrectly attribute the positive outcome to stable (unstable) causes experience higher (lower) job satisfaction than those with correct attributions, and (b) salespeople who incorrectly attribute the positive outcome to company-related (company-unrelated) causes experience higher (lower) job satisfaction than those with correct attributions.

H5. When actual performance is lower than expected, (a) salespeople who incorrectly attribute the negative outcome to stable (unstable) causes experience lower (higher) job satisfaction than those who with correct attributions, and (b) salespeople who incorrectly attribute the negative outcome to company-related (company-unrelated) causes experience lower (higher) job satisfaction than those with correct attributions. 


\section{Research method}

To test the causality between performance attributions and job satisfaction, a $2 \times 2 \times 2$ scenario-based between-subjects experimental study was conducted. The three experimental variables at two levels are performance outcome (higher or lower than an assigned quota), causal stability (stable/unstable cause), and company-related attributions (company-related/-unrelated cause). The scenario involves a fictitious salesperson named Chris, who works at an IT computing service provider. To create appropriate and relevant manipulations about company-related/-unrelated causes that may influence sales performance, a panel of 10 sales professionals from the IT industry were asked to provide the potential causes explaining a salesperson's performance achievement. The company-related causes they noted include marketing campaigns, IT-enabled customer relationship management, and cross-functional collaboration (e.g., product launching, delivery operations). The company-unrelated causes were associated with competitor actions and unexpected market changes. Appendix 1 provides the scenario and manipulations. As "Chris" can be short for names such as Christopher and Christian, a potential gender bias could affect the results. A t-test assessed the distribution of the responses of the male and female participants in the final study; the results show no significant difference in the related constructs (e.g., job satisfaction, $p=.84>.1$ ).

\section{Scenario pretest and manipulation check}

Two marketing research scholars were asked to evaluate the scenarios and run a Q-sort test, which required them to match the scenario with manipulated constructs and the two causal dimensions: stable/unstable and company-related/-unrelated causes. The goals were to check for clarity and readability and to ensure that the manipulations worked as intended. Then, a pretest was run with 107 international graduate students who had taken fundamental courses in marketing and sales at a major business school in France. Students were randomly assigned to a scenario and asked in an open-ended question to indicate the reasons specified in the scenario that explained the positive or negative 
performance outcome. The answers were content-analysed by one of the authors and a senior academic scholar using Elig and Frieze's (1975) method. Both coders rated their agreements on whether the students' responses fit the manipulations described. The percent agreement for the two raters is $87 \%$. The wording for one causal situation (success and environment-related cause) for which disagreement occurred was modified and then verified by an external judge. According to the results, the scenarios were judged reliable.

\section{Procedure and sample}

The final experimental study included salespeople from the Canadian manufacturing and business \& consumer service industries. Participants were assigned randomly to a scenario and asked to project themselves into Chris's situation and answer a questionnaire. The method of role-playing, which has been used in a variety of research contexts, is justified for situations that cannot be easily replicated in a lab experiment (e.g., Johnston and Kim, 1994). Role-playing is an expressive type of projective technique in which participants need to consider a particular situation and to interpret the behaviour of the actor; in doing so, they are likely to project their own motivations, beliefs, and feelings into the situation. According to Malhotra (2007), the more ambiguous the situation, the more participants project their emotions, motives, attitudes, and values.

Three commercial associations were contacted (i.e., a chambre de commerce in Eastern Canada, Canadian Professional Sales Association, and an automobile association) for participation of their business members. Invitation emails were sent to the general directors or sales directors of 108 firms. A follow-up telephone call was made one week after the invitation email. Twenty-two firms from six sectors, including pharmaceuticals, automobiles, insurance, industrial manufacturing, media, and consumer goods, agreed to participate. Participation was confidential and anonymous. The participating firms were promised provision of the results at the aggregate level. A survey package with an introduction letter describing the study's purpose and procedure was sent to salespeople. Two 
reminders were sent out in the second and third weeks after the survey was launched. The survey was distributed to 872 salespeople, and 226 questionnaires were returned (26.91\% response rate). After removal of 17 incomplete surveys, 209 usable responses remained. The final sample included 110 men and 99 women who had 6.49 years of sales experience on average with their current employers. The results of a non-response bias test (Armstrong and Overton, 1977) showed no significant differences between early and late responses in any of the major and demographic variables, suggesting that nonresponse bias is not a major concern in the data. With regard to age, $29 \%$ of participants were 30 years of age and younger, 29\% were between 30 and 40 years of age, $22 \%$ were between 40 and 50 years of age, and $20 \%$ were 50 years of age and older .

\section{Dependent variable: job satisfaction}

Participants were asked to rate their job satisfaction as Chris in the scenario. The concepts of salespeople's overall job satisfaction were adapted from Brown and Peterson (1994) and Darmon (2011), and four items measuring job satisfaction evaluated on a 7-point scale $(-3=$ very dissatisfied, $+3=$ very satisfied) were developed. Participants also rated organizational commitment and intention to leave on 7-point scales $(1=$ totally disagree, $7=$ totally agree $)$. These two variables served as constructs for assessing the validity of job satisfaction. Measure reliabilities and validity for the constructs were evaluated. The results show that (1) all items have significant factor loadings and no item has substantial cross-loadings, (2) the composite reliabilities are greater than $0.7,(3)$ the average variance extracted is greater than 0.5 . All the constructs have discriminant validity because the average variance extracted exceeds the squared correlations between all pairs of constructs (Fornell and Larcker 1981). Appendix 3 reports the items, the descriptive statistics and the results from confirmatory factor analysis.. The results also show a satisfactory model fit $\left(\chi^{2}=39.68, \mathrm{df}=30\right.$; root mean square error of approximation $=.04$; comparative fit index $=.99 ;$ standardized root mean square residual $=.04$ ). The 
mean of the four items of job satisfaction serve as the dependent variable in the analysis of variance (ANOVA).

\section{Perceptual attribution bias}

Attitude-attribution research identifies perceptual attribution bias as a systematic bias and proposes no objective standard for assessing attributional accuracy (Jones 1979; Ross 1977; Tetlock 1985). Investigating whether making people accountable can eliminate the fundamental attribution bias, Tetlock (1985) suggests that such biases are the product of an automatic processing routine. Observers still make biased inferences even when the stated position is clearly communicated. This bias effect resulting from an under-utilization of situational information and intuitive judgement has appeared across a wide range of manipulations.

The current experiment shows a similar finding. Attribution bias is a by-product of participants' attribution processes. When reading and projecting themselves into the scenario, the stimulus configurations produce this perceptual bias. Participants still make biased attributions when the scenario and manipulations are made clear to them. At the end of the questionnaire, participants answered two questions: (1) "What is the reason that best explains Chris's sales results (i.e., himself, the company, or an environmental factor)?" and (2) “Is this cause temporary or permanent?" Table III shows the number of observations in the assigned manipulated attributions and reported attributions. A chi-square test of goodness-of-fit between the two distributions $\left(\chi^{2}=81.73>\chi^{2}(2), p<.01\right)$ shows a significant difference in observations between the assigned and reported attributions. The participants still infer a significant degree of correspondence between the manipulated scenario and other causes they intuitively consider even when it is clearly stated that Chris made a company-related (or unrelated) attribution or a stable (or unstable) attribution. According to Tetlock (1985), the participants experience an attribution error. As such, perceptual bias is operationalised using the condition whether the manipulated cause matches the reported one. With mismatches, the participant experiences an 
attribution bias. Next, an ANOVA was run with two additional dummy variables: biased or unbiased perceptions of stability and company-related attributions.

Table III here

\section{Results}

Table IV and Table V report the means and the standard deviations of salespeople's job satisfaction from the different treatment groups. The ANOVA results show a significant effect of perceived performance outcome on salespeople's job satisfaction $(\mathrm{F}=109.22, p<.01)$; thus, H1 is supported. As Table IV shows, when salespeople make unbiased attributions (i.e., they attributed success or failure in line with the manipulation), attributions of stability have a significant effect on job satisfaction in both successful (actual performance $>$ expected performance; $\mathrm{F}=11.23, p<.01$ ) and unsuccessful (actual performance $<$ expected performance; $\mathrm{F}=12.65, p<.01$ ) cases; thus, $\mathrm{H} 2 \mathrm{a}$ and $\mathrm{H} 2 \mathrm{~b}$ are supported. However, for company-related attributions, the results show no significant effect when actual performance is greater than expected performance $(\mathrm{F}=.38, p=.54)$ but a significant effect on job satisfaction when actual performance is lower than expected $(\mathrm{F}=13.61, p<.01)$. These results provide support for $\mathrm{H} 3 \mathrm{~b}$, but not $\mathrm{H} 3 \mathrm{a}$.

-------- Tables IV and V here

\section{Effect of attribution bias}

As Table V shows, the results from biased and unbiased attributions on job satisfaction are mixed. For causal stability, when actual performance is greater than expected performance, there is a significant effect of salespeople with unbiased attributions and those with biased attributions on job satisfaction (F $=4.18, p<.05)$. Salespeople who incorrectly attribute their good performance to stable causes perceive higher job satisfaction $(\mathrm{M}=2.10, \mathrm{SD}=.38)$ than those who correctly attribute the outcome to unstable causes $(\mathrm{M}=1.55, \mathrm{SD}=.13)$. Salespeople who incorrectly attribute their good performance to unstable 
causes have lower job satisfaction $(\mathrm{M}=1.85, \mathrm{SD}=.17)$ than those who correctly attribute their performance to stable causes $(\mathrm{M}=2.26, \mathrm{SD}=.15)$; thus, $\mathrm{H} 4 \mathrm{a}$ is supported. However, when actual performance is lower than expected performance, the effects are not significant $(\mathrm{F}=.007, p=.93)$; thus, H4b is not supported.

Regarding company-related attributions, when actual performance is greater than expected, there is no significant interaction effect of biased and unbiased attributions on job satisfaction $(\mathrm{F}=.22, p=$ .64). H5a is not supported. However, when actual performance is lower than expected, the interaction effect of biased and unbiased attributions on job satisfaction is significant $(\mathrm{F}=4.47, p<.05)$. As Table IV shows, when the correct cause is company-unrelated, salespeople incorrectly attributing the poor performance to company-related causes experience lower satisfaction $(\mathrm{M}=.05, \mathrm{SD}=.33)$ than those with correct attributions $(\mathrm{M}=.98, \mathrm{SD}=.23)$. However, when the real cause is company-related, salespeople incorrectly attributing the poor performance to company-unrelated causes experience higher satisfaction $(\mathrm{M}=.13, \mathrm{SD}=.32)$ than those with correct attributions $(\mathrm{M}=-.07, \mathrm{SD}=.17)$; thus, $\mathrm{H} 5 \mathrm{~b}$ is supported.

Post hoc analysis: interactions between the two properties of attribution.

To rule out possible interactions between stable/unstable attributions and company-related/-unrelated attributions when salespeople make unbiased attributions, a post hoc test was conducted. As Table VI shows, when actual performance is greater than expected, a significant interaction occurs $(\mathrm{F}=5.43, p<$ $.05)$. Job satisfaction is higher when the cause is stable and company-related $(\mathrm{M}=1.85, \mathrm{SD}=.26)$ than when the cause is unstable and company-related $(\mathrm{M}=1.83, \mathrm{SD}=.18)$. Similarly, salespeople's satisfaction is higher when the cause is stable and company-unrelated $(\mathrm{M}=2.40, \mathrm{SD}=.24)$ than when the cause is unstable and company-unrelated $(\mathrm{M}=1.37, \mathrm{SD}=.19)$. When a salesperson believes that the positive outcome is due to a company-unrelated factor (or environment-related factor) and that this effect will remain for a while, he or she experiences higher job satisfaction $(\mathrm{M}=2.40, \mathrm{SD}=.24)$ than 
salespeople in other situations. However, when actual performance is lower than expected, the interaction is not significant $(\mathrm{F}=1.46, p=.23)$. Although Weiner (1985) argues that some overlap can occur between the properties of attribution, such that company-related attribution may have characteristics in common with attributions of stability, the current results show a significant interaction effect in successful cases but not in unsuccessful cases. When salespeople are frustrated with the negative outcome, they will not feel more satisfaction or dissatisfaction from the interaction between the two causal attributions. An explanation may be related to the satisfaction effects derived from the primary appraisal and the secondary appraisal in Weiner's model. Further investigation is required to explain the interplay between the effects of performance appraisals and the causal attributions.

\section{Table VI here}

\section{Discussion}

\section{Theoretical contributions}

This research uses Weiner's (1985) theory as a theoretical lens to investigate the linkages between salespeople's achievement-related attributions and job satisfaction. While sales force literature has investigated the motivational impacts of salespeople's attributions, the attributional view of the formation of salespeople's affective reactions (e.g., satisfaction) remains unclear. The results show that salespeople's perceived success or failure of the outcome significantly influences their job satisfaction. In addition, this research identifies the role of attribution biase in salespeople's attribution-satisfaction process. The biased attributions result in inflated or deflated satisfaction - a misattributed satisfaction that is higher or lower than the salespeople would have experienced had they made proper causal attributions. The concept of misattributed satisfaction is a new concept to the literature. Researchers generally agree that salesperson job satisfaction is associated with the positive outcomes. Rarely, if at all, have studies assessed whether this satisfaction is deserved or justified. The implications for this 
level of unwarranted inflated or deflated satisfaction are interesting from both theoretical and managerial perspectives.

As Table IV shows, this study finds that a stable cause that salespeople give for explaining the outcome, either a positive or negative one, implies their belief of the continuation of the outcome, which drives their job satisfaction. The other attributional dimension tested is company-related attributions, which indicate salespeople's assignment of responsibility to the firm for the obtained outcome. Salespeople who blame the firm for poor performance experience lower satisfaction than those who attribute the performance to company-unrelated causes. For example, a firm's losing $2 \%$ of market share to a competitor can be attributed to issues within the firm (e.g., ineffective sales policies) or the competitor's technological innovation. Blaming the firm may lead to dissatisfaction. This ascription may also imply salespeople's belief in the firm's competence to solve the problem.

Conversely, salespeople who give credit to the firm for good performance do not necessarily feel more satisfied than those who attribute the result to company-unrelated causes. A possible explanation is that the firm has responsibility to provide a satisfying selling environment to increase sales performance. Thus, salespeople do not feel more satisfaction when the firm is doing its job, as they merely expect it. The findings confirm an assumption of Weiner's theory that cognitive appraisals of the outcome of an event refine affective experiences. The results also align with expectation disconfirmation theory on the linkage between expectation disconfirmation and satisfaction (Oliver, 1980).

Figure 2 here

Salespeople experience an unbiased level of job satisfaction when making correct attributions. As panel A of Figure 2 shows, a salesperson who incorrectly attributes the merit of positive outcomes to a stable cause tends to believe in the continuity of the positive outcome, but the right cause is actually 
unstable. So, the salesperson experiences inflated (misattributed) satisfaction; the salesperson experiences higher satisfaction than what he or she reasonably should.

In unsuccessful cases, when the salesperson incorrectly attributes the negative outcome to an unstable cause, though the real cause is stable, inflated satisfaction should result. However, the results show no significant difference in satisfaction between salespeople with biased and those with unbiased perceptions of causal stability. A possible explanation is that the salesperson is overwhelmed by the poor outcome and does not recover from the expected amount of satisfaction derived from the attribution bias. That is, dissatisfaction is not improved even though the salesperson wrongly believed this failure would be temporary.

In successful cases, job satisfaction should be higher when salespeople they incorrectly attribute success to company-related causes than for salespeople with correct attributions. However, the results show that job satisfaction does not significantly change whether salespeople correctly or incorrectly credit the company. Satisfaction resulting from performance appraisals is not enhanced or weakened by the attribution bias. However, perceptions of company-related causes are more effective in contributing to salespeople's job satisfaction in unsuccessful than successful cases.

In unsuccessful cases, when a salesperson wrongly blames the firm for being responsible for the negative outcome (the actual cause is company-unrelated), he or she experiences deflated (misattributed) dissatisfaction; the salesperson experiences lower satisfaction than salespeople making correct attributions (see Figure 2, panel D). When a salesperson wrongly attributes the negative outcome to a company-unrelated cause (the actual cause is company-related), the salesperson experiences inflated (misattributed) satisfaction; he or she experiences higher satisfaction than salespeople making correct attributions. 
If people have an inflated sense of satisfaction, they might consider their performance beyond their actual abilities and could experience stagnation or a lack of motivation to adopt new sales techniques or strategies for improvement. Alternatively, someone who has a deflated sense of satisfaction could spiral down a negative path or perceive him- or herself as unworthy of the current role. While sales research has discussed managing expectations versus reality in buyer-seller exchanges, it is also important to manage expectations and reality of performance at the salesperson level.

\section{Managerial contributions}

Recognizing the importance of job satisfaction in an employee's performance, organizational commitment, and willingness to stay, is not an original concept. The main contribution of this research is the novel insight it brings to the role of managers in implementing procedures that ensure salespeople's "true" satisfaction (i.e., satisfaction based on performance appraisal) and the right assessment of the causal attribution following the performance outcome. Often salespeople play the "blame" game when they are unable to achieve their sales goals. Understanding the importance of attribution (for both successes and failures) is not only critical to managing salesperson expectations (and ultimately satisfaction), but also important for establishing trust and thoughtful communication between sales managers and their teams. Our findings suggest several managerial interventions for effective management of sales force satisfaction (some are identified in Figure 1).

Early intervention: setting realistic quotas to ensure sales force satisfaction. As the findings show, salespeople's understanding of assigned objectives substantially results in job satisfaction. Many salespeople do not meet their quotas in large part because of the over-optimistic quotas companies set, which leads to lower satisfaction, in turn resulting in low motivation and customer satisfaction. Instead, objectives should be based on a realistic assessment of salespeople's actual performance. Establishing 
sales objectives (e.g., sales quotas, customer satisfaction) in collaboration with salespeople can give managers an accurate idea of salespeople's expectations. While most companies want to establish and achieve ambitious growth strategies, sales managers should include the salespeople in the development of sales goals as the salesperson has the most insights for their market. For example, if a salesperson engages a new client for a larger order in year one that does not require yearly replenishment, that salesperson should not be expected to exceed that growth the following year. Regular reviews of the objective-performance relationship would enable managers to assist in salespeople's objective achievements, as well as manage expectations, potentially leading to high job satisfaction. Furthermore, working with the salesperson to develop the goals increases transparency and offers the salesperson a sense of ownership in his/her role.

Timely intervention: re-establishing sales force satisfaction through correct causal attributions and correcting attribution biases to obtain "true" and constant satisfaction for motivation. This study provides insights into the underlying attribution-satisfaction mechanisms following salespeople's performance appraisals. It highlights sales managers' involvement for correct measures to influence salespeople's attributions and responses, which in turn lead to sales force satisfaction. In other words, a good understanding of salespeople's correct attributions can help managers take effective actions for ensuring their satisfaction. This finding resonates with HR literature on how a manager's involvement in employees' perception-attribution processes and shapes their attitudinal and behavioural reactions (e.g., Niza et al., 2008; Piening et al., 2014; Tomlinson and Carnes, 2015). When a salesperson believes that the cause of the good performance is only temporary, which implies expectations of future failure, the manager should help him or her understand why this cause occurred to ensure satisfaction that leads to high motivation.

Frequent check-ins and opportunities for dyadic exchanges can help mitigate misattribution issues before the performance appraisal occurs. Offering salespeople the opportunity to ask questions 
and obtain information on a routine basis can not only decrease issues with information asymmetry, it can minimize speculation. Often misattribution may occur because of a lack of information or a feeling of "not belonging" to a company. Regular check ins and interventions can minimize these issues.

Managers need to be attentive to which factors salespeople attribute their good or poor performances. If the causal attribution is correct, managers should take every possible step to re-establish satisfaction, especially in the case of negative gaps. If the attribution is not correct, managers should educate salespeople on the true cause of their performance deviation. Here, managers should help remove the true causes of poor performance or reinforce the true causes of good performance. This requires the sales manager to be a good career coach and work with the salesperson to identify their strengths and opportunities for improvement. Professional development plans, beyond performance appraisals, with clear and measurable objectives and benchmarks can act as a guide for salespeople and keep them on track throughout the sales period.

Moreover, according to motivation theories (Locke and Latham, 2004), salespeople's motivation level indicates their involvement, intensity, and persistence of effort. According to the empirical findings, these aspects require continued anticipated satisfaction resulting from salespeople's correct attributions. An attribution error is a distortion of the reality of the actual situation and may lead to misattributed satisfaction and, potentially, poor decision making resulting from a misinterpretation of the situation. For example, if a salesperson incorrectly attributes a positive sales outcome to a stable product innovation, but this outcome is actually a result of a temporary sales promotion, he or she may experience misattributed satisfaction, which may lead him or her to believe that participating in sales training, a fundamental element, is not important.

Managers should also consider the ethical implications of manipulating job satisfaction. Managers might be tempted to inflate salesperson job satisfaction by evoking a biased or unbiased company misattribution. Not only is this an ethical violation, it is not sustainable. An inflated sense of 
job satisfaction will eventually incur a steep drop once the salesperson realigns, correctly, their attributions. This could have more debilitating and longer lasting effects that may be more difficult to overcome versus the salesperson just experiencing negative job satisfaction initially.

There are numerous reasons that a salesperson misattribution may occur. For example, the competitive environment could be extremely tumultuous during the year, salespeople may feel disconnected from the firm, sales managers may create overly ambitious goals, there could be operational challenges within the supply chain or marketing functions. Ultimately, it is hard to predict if and when a misattribution will occur. However, this research shows the potential negative implications of a misattribution on job satisfaction. Managers should deploy strategies and collaborative measures to minimize misattribution as much as possible in order to manage expectations, develop strong salespeople, and improve job satisfaction.

\section{Limitations and future research directions}

The results of this study must be considered in light of its limitations. One limitation is the lack of generalizability and predictive ability as indicated in the studies that tested the attribution-satisfaction causality using experiments (e.g., Folkes 1984). Clearly, there may be additional determinants of job satisfaction (e.g., Sohi 1996; Yilmaz 2002). Future research may consider a salesperson satisfaction model that must include beside attributions and enhance the predictive ability of such model with mutilple research methods. Another limitation is that the causal attributions are simulated, as is the case with many experimental studies in achievement-related contexts examining work motivations. Steps were taken to ensure that the participants were experienced with and knowledgeable about a selling environment.

In addition, as noted previously, the name "Chris" used in the scenario is likely to lead to gender bias (e.g., male or female participants may respond differently when the salesperson in the scenario is a 
man or a woman). Although a t-test showed no significant differences in responses between male and female participants, future research should take into account the potential gender bias resulted from the gender of the salesperson described in the scenario.

Another limitation pertains to the categories of causes. In terms of the locus of causality, this study treats the firm as the causal agent in the investigation of the attribution-satisfaction relationship. Selling today occurs in a participative environment; that is, in many cases, a salesperson's performance could be due to the combined efforts of the whole sales team, sales management, and the firm. Many times, sales performance requires inputs with some sense of equity/inequity among salespeople, sales management, and the firm. Thus, salespeople's perceptions of what level in an organizational hierarchy should accept responsibility for the outcome may differ. As such, research should develop novel methods (manipulated variables or self-reported data) to investigate salespeople's perceptions of the participation of different firm entities and their resulting attitudes and behaviours. Future research should take into account the nature of each causal attribution and the possible interaction effect between locus of control and causal stability. Moreover, although the categories of company-related/unrelated causes were created from a panel of 10 sales professionals, uncovering the factors to which salespeople attribute their performance is not a simple task. Future research might explore other categories and causes and use different methods and data sources to test their effects on the attitudes and behaviours of frontline employees.

With consideration of attribution bias, the participants still made biased attributions even when the scenario and manipulations were made clear to them. According to Tetlock (1985), this finding indicates that the participants experienced an attribution error. Although this study was inspired by the attitude-attribution experiments conducted in the 1970s, future research could explore adequate means to measure the fundamental attribution error and provide new insights into how to eliminate or correct it. 
Furthermore, the results show no difference in job satisfaction between salespeople with biased and unbiased perceptions of causal stability in the unsuccessful situation and no difference in satisfaction between salespeople with biased and unbiased perceptions of company-related attribution in the successful cases. A possible explanation is that the amount of satisfaction (or dissatisfaction) derived from the attribution bias (secondary appraisal) insufficiently recovers (weakens) the dissatisfaction (satisfaction) resulting from performance appraisal (primary appraisal). According to Weiner's (1985) theory, the cognition of the outcome (primary appraisal) and the cognition of the cause of the outcome (secondary appraisal) may occur simultaneously or sequentially, and both result in the individual's emotional state. Further investigation of the interplay between the satisfaction derived from primary and secondary appraisals is necessary. Research could explore psychological mechanisms following the primary appraisal and analyse the extent to which satisfaction resulting from the performance appraisal can be enhanced or weakened by the amount of satisfaction resulting from causal attributions. Understanding the effect size from both appraisals would enable managers to take better precautions when an attribution error is likely to occur at the secondary appraisal to ensure salespeople's constant and real satisfaction resulting from correct attributions.

In addition, future research could explore, at the more granular level, attributions made primarily to an immediate supervisor or colleague rather than more global attributions to a firm. Furthermore, when salespeople perceive a psychological contract breach, they have lower overall job satisfaction (Hartmann and Rutherford, 2015). Additional research could examine the misalignment of the psychological climate for salespeople and how misattributed causality impacts not only satisfaction but the overall workplace climate as well.

Finally, the conceptual domain of job satisfaction can also be defined from different perspectives (e.g., internal vs. external satisfaction, higher-order vs. lower-order satisfaction). Inclusion of other satisfaction determinants may also allow investigation of job satisfaction development. Future research 
could explore other potential causal models that explain the sources of job satisfaction to advance

knowledge of salespeople's job satisfaction development. For example, coping with salespeople in an

objective setting procedure can be a potential causal source. Job satisfaction may also be multifaceted.

Salespeople in particular may experience job satisfaction from a variety of factors, including

customers, co-workers, sales policies, flexibility, and work-life balance (Friend et al., 2013). Capturing

all these dimensions in one study is difficult. Future research could consider how misattributing success

affects various dimensions of job satisfaction using multifaceted scales.

\section{Appendix 1.}

\section{Part 1: All participants read the same background information}

Chris is a salesperson at SuperLan, a reputable computer manufacturer.

\section{SuperLan}

SuperLan produces portable IT devices, tablets and workstations designed for office engineering or architects and also provides IT computing services that help business partners to realise the physical and virtual information platforms in North America. Every quarter, SuperLan launches an advertising campaign in local business magazines and online. In addition, throughout the year, customers receive the firm's newsletter, which provides information on production, seasonal services, and promotions. Sales territories are divided by geographic area. All salespeople at SuperLan perform similar functions, but must develop their own strengths and tactics for selling specific workstations to different types of customers. Each sales rep is assigned a yearly sales quota and is required to update sales reports every week. At weekly sales meetings, salespeople are able to exchange their experiences and seek support from colleagues and management. Sales managers can also respond to the specific questions that salespeople may have for their own territories or their clients. The compensation plan and career development policies for salespeople are in line with industry practices. In addition, all salespeople have access to regular product or service training, which provides them with information they need to perform their duties.

\section{Market and competition}

The competition in IT service market is fierce. Two other companies operating in the same area also adopt aggressive marketing campaigns and regularly propose attractive promotional deals. Recently, one of the two competitors recalled a very large number of workstations because of data transferring defects. This had a big negative effect on their sales and triggered rumours that the company might soon be driven out of business. At about the same time, the other competitor launched an eco-efficient and energy-saving model to the market.

\section{Chris}

For the last three years, Chris has been a reasonably successful salesperson at SuperLan. Chris mainly deals with business customers. His persuasive abilities are above average and help him find good solutions and convince clients of their value. However, because product and service innovations develop rapidly, Chris sometimes faces a variety of inquiries from his different customers. It takes Chris time to develop appropriate communication techniques for presenting products and responding to the needs of specific customers, particularly small-size firms. Chris usually spends time learning, practicing selling tactics, and creating effective selling approaches. Chris routinely visits customers, gaining insights from their feedback, and communicate this feedback with SuperLan's different functional departments. 
Part 2: All participants were randomly assigned to one performance outcome condition and one attribution treatment accordingly

\section{Actual performance is greater than expected}

At the end of the year, quite unexpectedly, Chris's sales revenues were 20\% higher than his sales quota. When asked to share the feelings and explain the results, Chris said:

\section{Attribution treatment}

\section{Unstable and company-related}

"I think SuperLan's advertising campaigns are successful this year, especially the promotions geared towards my business clientele. I believe that this year's corporate quarterly marketing campaigns have effectively communicated with the types of customers that I serve and this has greatly facilitated my job. Thanks to these campaigns, I could effectively demonstrate the nice features and high quality of our products to my professional customers.... However, I doubt that next year's campaigns will be as effective. This year's campaigns are surprisingly successful.... Well, I do hope that our marketing campaigns can be as successful next year, but I strongly doubt it...they just cut a large amount of the advertising budget for next year, it is not guaranteed to have as effective advertising campaigns for my clientele next year."

\section{Stable and company-related}

"I think 'sales drive' is the key!! Sales drive is our new sales force automation (SFA) system. My company has not officially installed it. However, the system is under evaluation and my manager has asked me to give it a try and to provide feedback. Personally, I find it very user-friendly and it provides very precise sales planning analysis. The system also provides a mobile application that is really practical; I can easily update my sales calls and download customer information with my cell phone. My clients are business buyers. The sales drive has several functions to facilitate the complex selling tasks for my clientele. It made my job easier this year and that should continue when the firm adopts the new SFA system permanently. I heard from my manager that it is very likely that we will soon officially adopt sales drive."

\section{Unstable and company-unrelated}

"I think the main reason for my performance is because the competition in my territory has decreased. I just learned that the competitor's salesperson in my territory has resigned and his territory was vacant for some time before he was replaced. I actually received several inquiries from customers who used or are using the competitor's product and service.... However, I do not expect to benefit from the same situation for next year because the vacant sales position is now filled!!"

\section{Stable and company-unrelated}

"I think the whole environment has helped a lot for my business clientele. Being in charge of selling the multifunction printers to business customers, I have benefited from the product recall of our competitor. Most business customers always insist on purchasing highly dependable printers and many of them turned to me when the rumour of our competitor going out of business started circulating. Now, I am able to take advantage of this increased demand for our products from business customers. It will take quite a period of time for my competitor to recover and to back to the market. I think I can benefit from this situation for a few more years!!"

\section{Actual performance is lower than expected}

At the end of the year, quite unexpectedly, Chris's sales revenues were $20 \%$ lower than his sales quota. When asked to share the feelings and explain the results, Chris said:

\section{Attribution treatment}

Company-related and unstable 
“I think that SuperLan's marketing campaigns have been weak this year. Many of my business customers, with whom I am generally very effective, have been offended by our commercials. I had to spend plenty of time explaining and answering their questions concerning the confusing advertisements, you know, usually I will not have any problem with my business customers because of the quality of our marketing campaigns. I hope this situation is temporary. The marketing chief has promised to re-examine the quality of the campaigns and I believe that next year, our marketing campaigns and my sales performance will be back to their past quality levels."

\section{Company-related and stable}

"I have suffered greatly from our new product launching policy. Some of my business customers were ready to buy our new energy-saving printing system, but my territory was the last area to receive the new system. I could not have it until late fall this year. All other regions had started to sell it much earlier than I did. Several of my customers got impatient and chose to use our competitor's services... My manager told me that it would not get better until we changed the delivery system. I will have to deal with this problem for at least two more years!!

\section{Company-unrelated and unstable}

"At the beginning of the year, there was some rumour about the quality of the multifunction printers that I sell to my business customers, particularly the models for the smart document system. Some college students made up a story about the products on YouTube. The police officers have found out who they were. Although they have corrected the information and emphasised that the information was false, my sales results still suffered this year. We know that the impact is short-term and will eventually go away in a couple of weeks or months. For sure, my sales performance will be back soon."

\section{Company-unrelated and stable}

"I was doing very well until our main competitor started selling eco-efficient and energy-saving printers that strongly appeal to my business customers. Such customers are very sensitive to technical innovations that allow them to save on their costs.... It's hard to sell our products when our competitor has such strong innovation capabilities. The strength of our competitor has been the application of new techniques to its products for a long time. With such strong competition, I do not see my sales performance improving over the next few years."

Appendix 2. Correlations of the variables JS, OC and IS

\begin{tabular}{llll}
\hline & JS & OC & IS \\
\hline JS & 1 & & \\
OC & $.53 * *$ & 1 & 1 \\
IS & $.48^{* *}$ & $.65^{* *}$ & 4.41 \\
Mean & 1.03 & 4.81 & 1.32 \\
SD & 1.32 & 1.34 & \\
\hline
\end{tabular}

$\mathrm{JS}=$ overall job satisfaction, $\mathrm{OC}=$ organisational commitment, $\mathrm{IS}=$ intention to stay

**Correlation is significant at the $1 \%$ level (2-tailed); *Correlation is significant at the $5 \%$ level (2-tailed). 
Appendix 3.

Final measures and CFA results

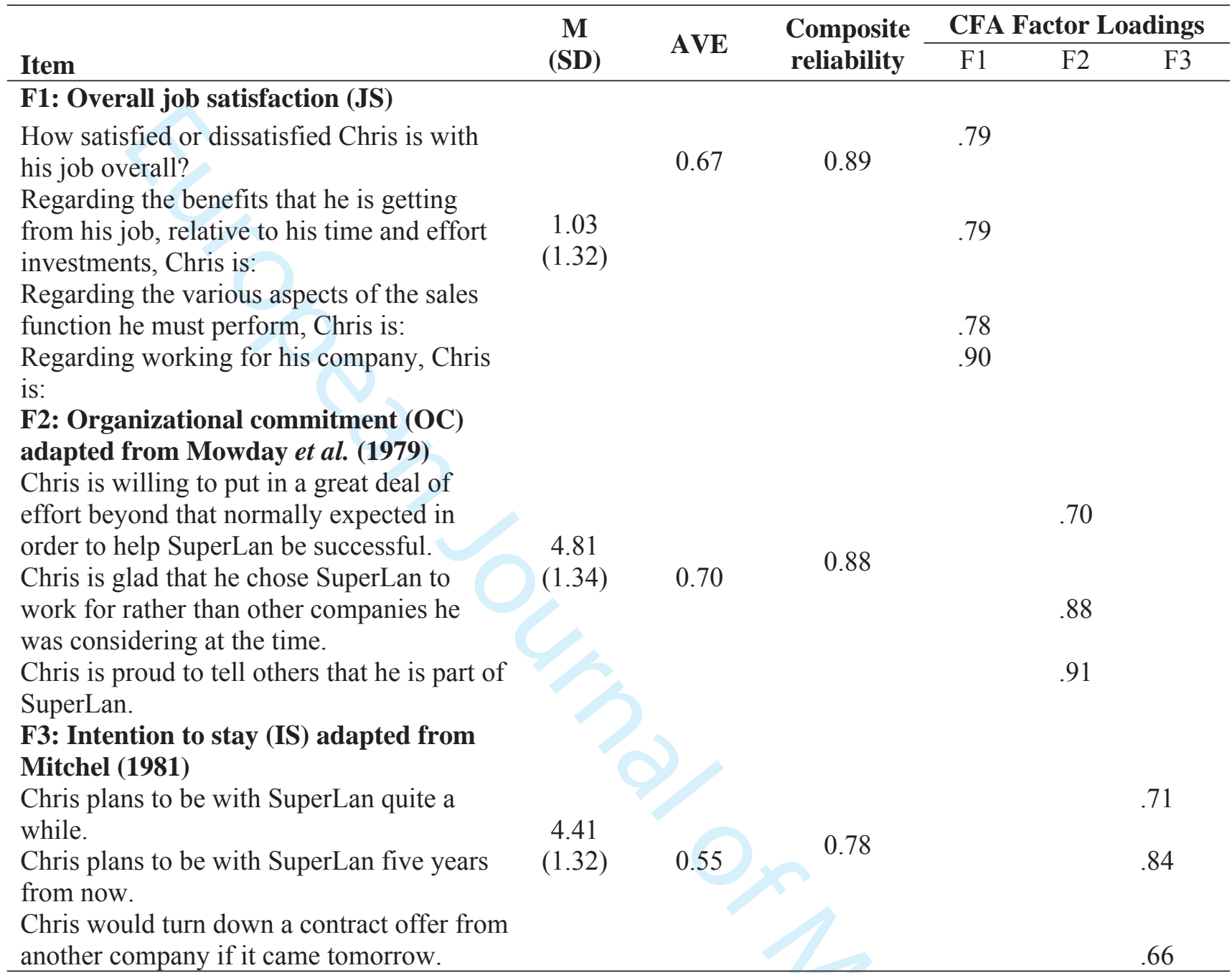

$\mathrm{M}=$ mean, $\mathrm{SD}=$ standard deviations, $\mathrm{AVE}=$ average variance extracted 


\section{References}

Allison, L., Flaherty, K.E, Jung, J.H. and Washburn, I. (2016), "Salesperson brand attachment: a job demands-resources theory perspective", Journal of Personal Selling \& Sales Management, Vol. 36 No. 1, pp. 3-18.

Armstrong, J.S. and Overton, T.S. (1977), "Estimating nonresponse bias in mail surveys", Journal of Marketing Research, Vol. 14 No. 3, pp. 396-402.

Badovick, G.J. (1990), "Emotional reactions and salesperson motivation: an attributional approach following inadequate sales performance", Journal of the Academy of Marketing Science, Vol 18 No. 2, pp. 123-130.

Badovick, G.J., Hadaway, F.J. and Kaminski, P.F. (1992), “Attributions and emotions: the effects on salesperson motivation after successful vs. unsuccessful quota performance", Journal of Personal Selling \& Sales Management, Vol. 12 No. 3, pp. 1-11.

Bazerman, M.H. and Moore, D. (2009), Judgment in Managerial Decision Making, 7th ed., Wiley, Denver.

Boichuk, J.P., Bolander, W., Hall, Z.R., Ahearne, M., Zahn, W.J. and Nieves, M. (2014), "Learned helplessness among newly hired salespeople and the influence of leadership", Journal of Marketing, Vol. 78 No. 1, pp. 95-111.

Bridges, E., Johnston, H.H. and Sager, J.K. (2007), "Using model-based expectations to predict voluntary turnover”, International Journal of Research in Marketing, Vol. 24 No. 1, pp. 65-76.

Brown, S.P. and Peterson, R.A. (1994), "The effect of effort on sales performance and job satisfaction", Journal of Marketing, Vol. 58 No. 2, pp. 70-80.

Clore, G.L. and Ortony, A. (2008), “Appraisal theories: how cognition shapes affect into emotion”, in Lewis, M., Haviland-Jones, J.M. and Barrett, L.F. (Ed.), Handbook of Emotions, 3rd ed., Guilford Press, New York, NY, pp. 628-642.

Chung, D. J. (2015), “How to Really Motivate Salespeople,” Harvard Business Review, 93 (4), 54-61.

Darmon, R.Y. (2011), "Processes underlying the development and evolution of salespersons' job satisfaction/dissatisfaction: a conceptual framework", Canadian Journal of Administrative Sciences / Revue Canadienne des Sciences de l'Administration, Vol. 28 No. 4, pp. 388-401.

DeCarlo, T.E., Agarwal, S. and Vyas, S.B. (2007), "Performance expectations of salespeople: the role of past performance and causal attributions in independent and interdependent cultures", Journal of Personal Selling \& Sales Management, Vol. 27 No. 2, pp. 133-147.

DeCarlo, T.E., Teas, R.K. and McElroy, J.C. (1997), "Salesperson performance attribution processes and the formation of expectancy estimates", Journal of Personal Selling \& Sales Management, Vol. 17 No. 3, pp. 1-17.

Dixon, A.L., Forbes, L.P. and Schertzer, S.M.B. (2005), "Early success: how attributions for sales success shape inexperienced salespersons' behavioral intentions", Journal of Personal Selling and Sales Management, Vol. 25 No. 1, pp. 67-77.

Dixon, A.L. and Schertzer, S.M.B. (2005), "Bounching back: how salesperson optimism and self-efficacy influence attributions and behaviors following failure", Journal of Personal Selling \& Sales Management, Vol. 25 No. 4, pp. 361-369. 
Dixon, A.L., Spiro, R.L. and Forbes, L.P. (2003), “Attributions and behavioral intentions of inexperienced salespersons to failure: an empirical investigation", Journal of the Academy of Marketing Science, Vol. 31 No. 4, pp. 459-467.

Dixon, A.L., Spiro, R.L. and Jamil, M. (2001), "Successful and unsuccessful sales calls: measuring salesperson attributions and behavioral intentions", Journal of Marketing, Vol. 65 No. 3, pp. 64-78.

Elig, T.W. and Frieze, I.H. (1975), "A multi-dimensional scheme for coding and interpreting perceived causality for success and failure events: The Coding Scheme of Perceived Causality, CSPC. Catalog of Selected Documents in Psychology, Vol. 5 No. 313, MS No. 1069.

Fang, E., Evans, K.R. and Landry, T.D. (2005), "Control systems' effect on attributional processes and sales outcomes: a cybernetic information-processing perspective", Journal of the Academy of Marketing Science, Vol. 33 No. 4, pp. 553-574.

Friend, S.B., Johnson, J.S., Rutherford, B.N. and Hamwi, G.A. (2013), "INDSALES model: a facet-level job satisfaction model among salespeople”, Journal of Personal Selling \& Sales Management, Vol. 33 No. 4, pp. 419-438.

Folkes, V. S. (1984), “Consumer reactions to product failure: An attributional approach", Journal of Consumer Research, Vol. 10 No. 4, pp. 398-409.

Folkes, V.S. (1988). "Recent attribution research in consumer behavior: a review and new directions.", Journal of Consumer Research, Vol. 14 No. 4, pp. 548-565

Fornell, C. and Larcker, D. F. (1981), "Evaluating structural equation models with unobservable variables and measurement error," Journal of Marketing Research, Vol. 18 No. 1, Pp. 39-50.

Hartmann, N.N. and Rutherford, B.N (2015), "Psychological contract breach's antecedents and outcomes in salespeople: the roles of psychological climate, job attitudes, and turnover intention", Industrial Marketing Management, Vol. 51, pp.158-170.

Heider, F. (1958), The Psychology of Interpersonal Relations, Erlbaum, Hillsdale, NJ.

Hewett, R., Shantz A., Mundy, J. and Alfes, K. (2018), "Attribution theories in human resource management research: a review and research agenda", International Journal of Human Resource Management, Vol. 29 No. 1, pp. 87-126.

Huber, V.L., Podsakoff, P.M. and Todor, W.D. (1986), "An investigation of biasing factors in the attributions of subordinates and their supervisors", Journal of Business Research, Vol. 14 No. 1, pp. 83-98.

Johnson, M.S. (2006), “A bibliometric review of the contribution of attribution theory to sales management”, Journal of Personal Selling \& Sales Management, Vol. 26 No. 2, pp. 181-195.

Johnston, W.J. and Kim, K. (1994), "Performance, attribution, and expectancy linkages in personal selling”, Journal of Marketing, Vol. 58 No. 4, pp. 68-81.

Jones, E.E. (1979), “The rocky road from acts to dispositions”, American Psychologist, Vol. 34 No. 2, pp. 107-117.

Keren, G. and Teigen, K.H. (2004), "Yet another look at the heuristics and biases approach", in Koehler, D.J. and Harvey, N. (Eds.), Blackwell Handbook of Judgment and Decision Making, Blackwell Publishing, pp. 1-20.

Lai, C.J and Gelb, B. (2019), "Another look at motivation and retaining salespeople”, Journal of Business Strategy, Vol. 40 No. 4, pp. 11-17. 
Langdridge, D. and Butt, T. (2004), "The fundamental attribution error: a phenomenological critique", British Journal of Social Psychology, Vol. 43 No. 3, pp. 357-369.

Locke, E.A. (1976), "The nature and causes of job satisfaction", in Dunnette M.D. (Ed.), Handbook of Industrial and Organizational Psychology, Rand McNally, Chicago, IL., pp. 1297-1350.

Locke., E.A. and Latham., G.P. (2004), "What should we do about motivation theory? Six recommendations for the twenty-first century", Academy of management Review, Vol. 29 No. 3, pp. 388-403.

Malhotra, N.K. (2007), Marketing Research: An Applied Orientation, Pearson Prentice Hall, India.

Malle, B.F. (1999), "How people explain behavior: a new theoretical framework", Personality and Social Psychology Review, Vol. 3 No. 1, pp. 23-48.

Mallin, M.L. and Mayo, M. (2006), "Why did I lose? A conservation of resources view of salesperson failure attributions", Journal of Personal Selling \& Sales Management, Vol. 26 No. 4, pp. 345-357.

Marshall, G.W., Moncrief, W.C., Lassk, F.G. and Shepherd, C.D. (2012), "Linking performance outcomes to salesperson organizational citizenship behavior in an industrial sales setting", Journal of Personal Selling \& Sales Management, Vol. 32 No. 4, pp. 491-502.

Mayo, M. and Mallin, M.L. (2010), "The impact of sales failure on attributions made by 'resourcechallenged' and 'resource-secure' salespeople", Journal of Marketing Theory \& Practice, Vol. 18 No. 3, pp. 233-247.

McArthur, L.Z. and Baron, R. (1983), “Toward an ecological theory of social perception”, Psyhological Review, Vol. 90, pp. 215-238

Mitchel, J.O. (1981), “The effect of intentions, tenure, personal, and organizational variables on managerial turnover", Academy of Management Journal, Vol. 24 No. 4, pp. 742-751.

Moorman, R. H. (1993), "The Influence of Cognitive and Affective Based Job Satisfaction Measures on the Relationship between Satisfaction and Organizational Citizenship Behavior," Human Relations, 46 (6), 759-76.

Mowday, R.T. Steers, R.M., and Porter, L.W. (1979), "The measurement of organizational commitment”, Journal of Vocational Behavior, Vol. 14 No. 2, pp. 224-247.

Nishii, L.H., Lepak, A.M. and Schneider, B. (2008), "Employee attributions of the 'WHY' HR practices: their effects on employee attitudes and behavior, and customer satisfaction", Personnel Psychology, Vol. 61 No. 3, pp. 503-545.

Niza, C., Silva, S. and Lima, M.L. (2008), “Occupational accident experience: Association with workers' accident explanation and definition”, Safety Science, Vol. 46 No. 6, pp. 959-971.

Oliver, R.L. (1980), "A cognitive model of the antecedents and consequences of satisfaction decisions", Journal of Marketing Research, Vol. 17 No. 4, pp. 460-469.

Onyemah, V., Swain, S.D. and Hanna, R. (2010), “A social learning perspective on sales technology usage: Preliminary evidence from an emerging economy”, Journal of Personal Selling \& Sales Management, Vol. 30 No. 2, pp. 131-142.

Pettijohn, C.E, Pettijohn, L.S. and d'Amico, M. (2001), "Characteristics of performance appraisals and their impact on sales force satisfaction”, Human Resource Development Quarterly, Vol. 12 No. 2, pp. 127-146. 
Piening, E.P, Baluch, A.M and Ridder, H.-G. (2014), "Mind the intended-implemented gap: understanding employees' perceptions of HRM”, Human Resource Management, Vol. 53 No. 4, pp. 545-567.

Reisenzein, R. (2014), "The attributional approach to emotion and motivation: introduction to a special section of emotion review", Emotion Review, Vol. 6 No. 4, pp. 332-35.

Ross, L. (1977), "The intuitive psychologist and his shortcomings: distortions in the attribution process", Advances in Experimental Social Psychology, Vol. 10, pp. 173-220.

Rutherford, B.N., Hamwi, G.A., Friend, S.B. and Hartmann, N.N. (2011), "Measuring salesperson burnout: A reduced maslach burnout inventory for sales researchers", Journal of Personal Selling \& Sales Management, Vol. 31 No. 4, pp. 429-440.

Seriki, O.K., Evans, K.R., Jeon, H.-J., Dant, R.P. and Helm, A. (2016), "Unintended effects of marketing messages on salespeople's cynicism”, European Journal of Marketing, Vol. 50 No. (5/6), pp. 10471072

Silvester, J., Patterson, F. and Ferguson, E. (2003), "Comparing two attributional models of job performance in retail sales: a field study", Journal of Occupational \& Organizational Psychology, Vol. 76 No. 1, pp. 115-132.

Shipley, D. and Kiely, J. (1988), "Motivation and dissatisfaction of industrial salespeople - How relevant is Herzberg's Theory?”, European Journal of Marketing, Vol. 22 No. 1, pp. 17-30.

Sohi, R. S. (1996), “The effects of environmental dynamism and heterogeneity on salespeople's role perceptions, performance and job satisfaction", European Journal of Marketing, Vol. 30 No. 7, pp. 4967.

Steenburgh, T. and Ahearne, M. (2012), "Motivating salespeople: What really works," Harvard Business Review, 90 (7/8), 70-75.

Sujan, H. (1986), "Smarter versus harder: an exploratory attributional analysis of salespeople's motivation”, Journal of Marketing Research, Vol. 23 No. 1, pp. 41-49.

Teas, R.K. and McElroy, J.C. (1986), "Causal attributions and expectancy estimates: a framework for understanding the dynamics of salesforce motivation", Journal of Marketing, Vol. 50 No. 1, pp. 75-86.

Tetlock, P.E (1985), “Accountability: a social check on the fundamental attribution error", Social Psychology Quarterly, Vol. 48 No. 3, pp. 227-236.

Tetlock, P.E. and Levi, A. (1982), "Attribution bias: on the inconclusiveness of the cognition-motivation debate", Journal of Experimental Social Psychology, Vol. 18 No. 1, pp. 68-88.

Tomlinson, E.C. and Carnes, A.M. (2015), "When promises are broken in a recruitment context: the role of dissonance attributions and constraints in repairing behavioural integrity", Journal of Occupational \& Organizational Psychology, Vol. 88 No. 2, pp. 415-435.

Vink, J. and Verbeke, W. (1993), “Adaptive selling and organizational characteristics: suggestions for future research", Journal of Personal Selling \& Sales Management, Vol 13 No. 1, pp. 15-23.

Wang, G. and Ma, X. (2013), "The effect of psychological climate for innovation on salespeople's creativity and turnover intention", Journal of Personal Selling \& Sales Management, Vol. 33 No. 4, pp. 373-388.

Weiner, B. (1985), "An attributional theory of achievement motivation and emotion", Psychological Review, Vol. 92 No. 4, pp. 548-573. 
Weiner, B. (2014), "The attribution approach to emotion and motivation: history, hypotheses, home runs, headaches/heartaches", Emotion Review, Vol. 6 No. 4, pp. 353-361.

Weiss, H.M. and Cropanzano, R. (1996), "Affective events theory: a theoretical discussion of the structure, causes and consequences of affective experiences at work", in Staw, B.M. and Cummings, L.L. (Eds.), Research in Organizational Behavior: An Annual Series of Analytical Essays and Critical Reviews, Vol. 18, Elsevier Science/JAI Press, pp. 1-74.

Weiss, H.M., Nicholas, J.P. and Daus, C.S. (1999), "An examination of the joint effects of affective experiences and job beliefs on job satisfaction and variations in affective experiences over time", Organizational Behavior and Human Decision Processes, Vol. 78 No. 1, pp. 1-24.

Yilmaz, C. (2002), "Salesperson performance and job attitudes revisited: An extended model and effects of potential moderators", European Journal of Marketing, Vol. 36 No. 11/12, pp. 1389-414.

Zablah, A.R., Carlson, B.D., Donavan, D.T., Maxham III, J.G. and Brown, T.J. (2016), “A cross-lagged test of the association between customer satisfaction and employee job satisfaction in a relational context", Journal of Applied Psychology, Vol. 101 No. 5, pp. 743-755. 


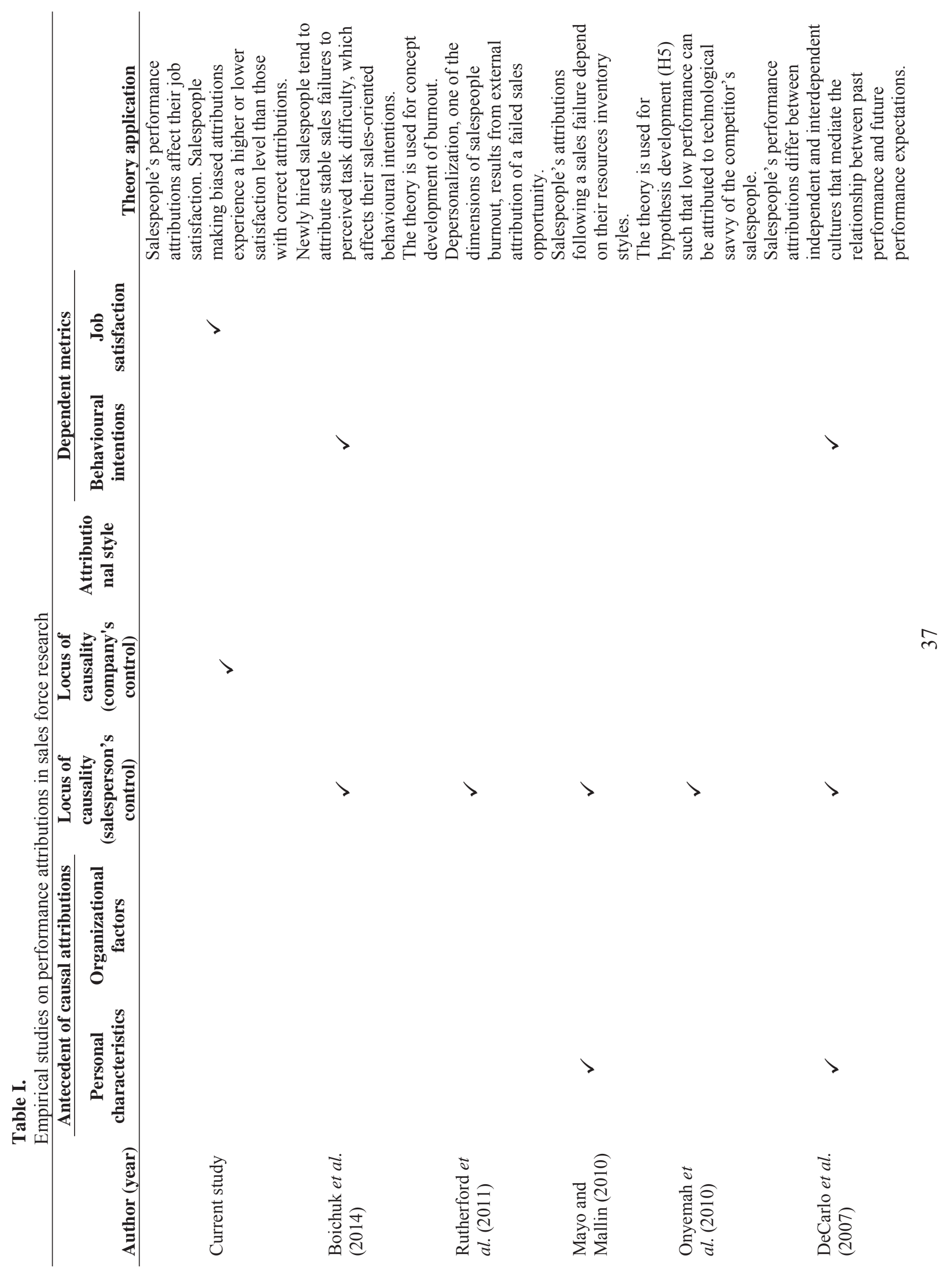



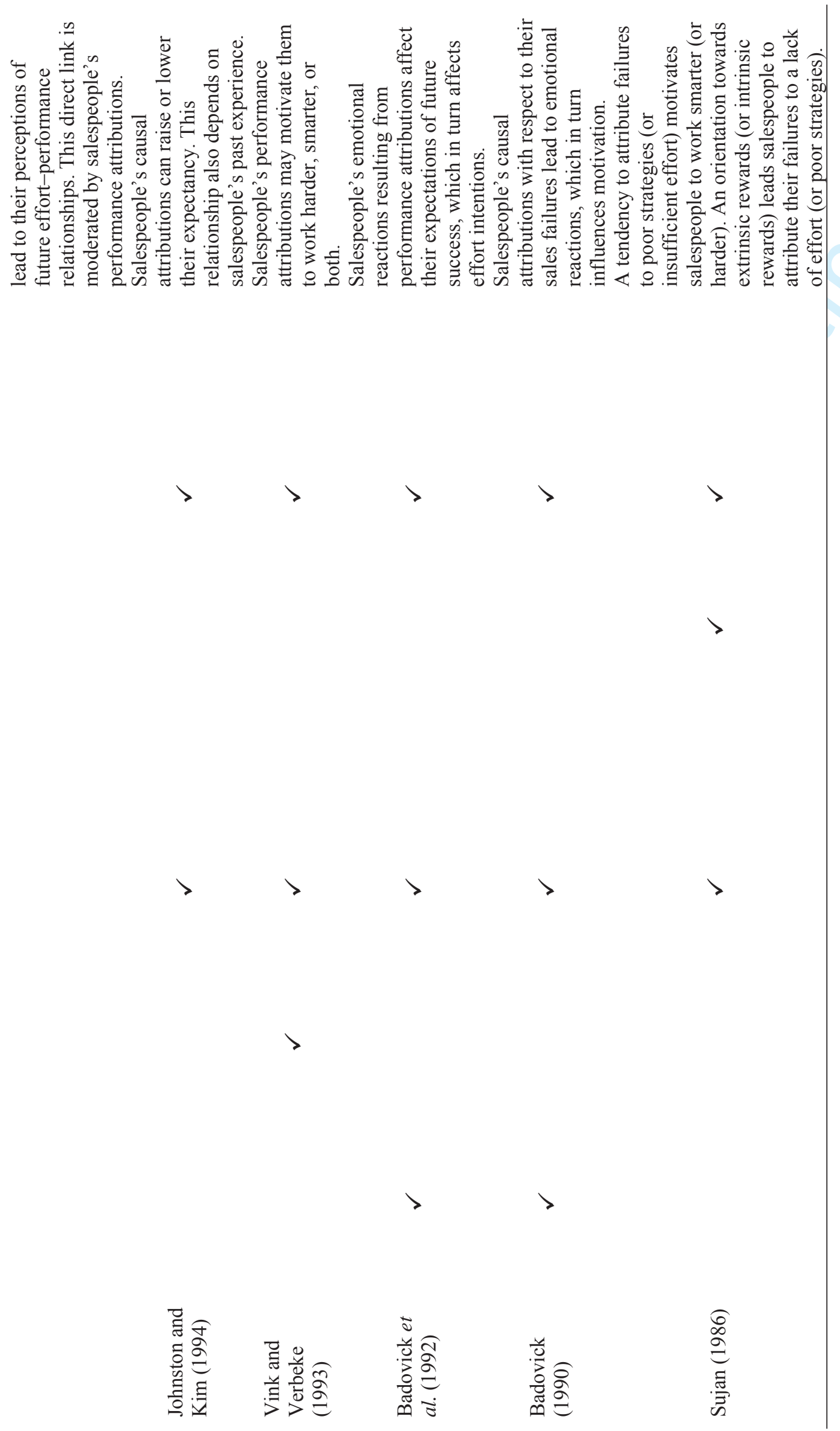
Table II.

Constructs and definitions

\begin{tabular}{|c|c|c|}
\hline Construct & Definition & Reference \\
\hline Overall job satisfaction & $\begin{array}{l}\text { Job satisfaction refers to an overall positive } \\
\text { emotional appraisal of the job. }\end{array}$ & $\begin{array}{l}\text { Moorman, 1993; } \\
\text { Locke, } 1976\end{array}$ \\
\hline Stable/unstable causes & $\begin{array}{l}\text { The stability of a cause refers to its perceived } \\
\text { fluctuation over time. A stable cause remains } \\
\text { consistent over time, whereas an unstable cause is } \\
\text { subject to changing under temporal conditions. }\end{array}$ & Weiner, 1985 \\
\hline $\begin{array}{l}\text { Company-related/- } \\
\text { unrelated causes }\end{array}$ & $\begin{array}{l}\text { Causal attributions lie within an organization's } \\
\text { control. A company-related cause is a factor for } \\
\text { which a company is responsible or over which it has } \\
\text { control. A company-unrelated cause is beyond a } \\
\text { company's control (i.e., absent company's voluntary } \\
\text { intention). The company is perceived as a passive } \\
\text { recipient of environmental forces. }\end{array}$ & Nishii et al., 2008 \\
\hline Perceptual attribution bias & $\begin{array}{l}\text { The tendency of a salesperson to attribute the actor's } \\
\text { (company's) behaviour or action to company- } \\
\text { associated qualities rather than situational factors. } \\
\text { The salesperson intuitively selects data, assesses the } \\
\text { company's intentionality, and is less concerned } \\
\text { about the situational cues. }\end{array}$ & $\begin{array}{l}\text { Heider, 1958; } \\
\text { Langdridge and Butt, } \\
\text { 2004; Ross, } 1977\end{array}$ \\
\hline
\end{tabular}

Table III.

Observations in the assigned and reported attributions

\begin{tabular}{ccccccc}
\hline & $\begin{array}{c}\text { Attribution } \\
\text { treatment }\end{array}$ & \multicolumn{2}{c}{ Company-related } & \multicolumn{2}{c}{ Company-unrelated } & \\
& Unstable & Stable & Unstable & Stable & Total \\
\hline $\begin{array}{c}\text { Actual }>\text { expected } \\
\text { performances }\end{array}$ & Manipulated & 26 & 25 & 21 & 29 & 101 \\
& Reported & 24 & 13 & 43 & 21 & 101 \\
$\begin{array}{c}\text { Actual }<\text { expected } \\
\text { performances }\end{array}$ & $\begin{array}{c}\text { Manipulated } \\
\text { Reported }\end{array}$ & 22 & 43 & 23 & 20 & 108 \\
\hline
\end{tabular}


Table IV.

Means and standard deviations of job satisfaction (JS) for good and poor performance outcomes

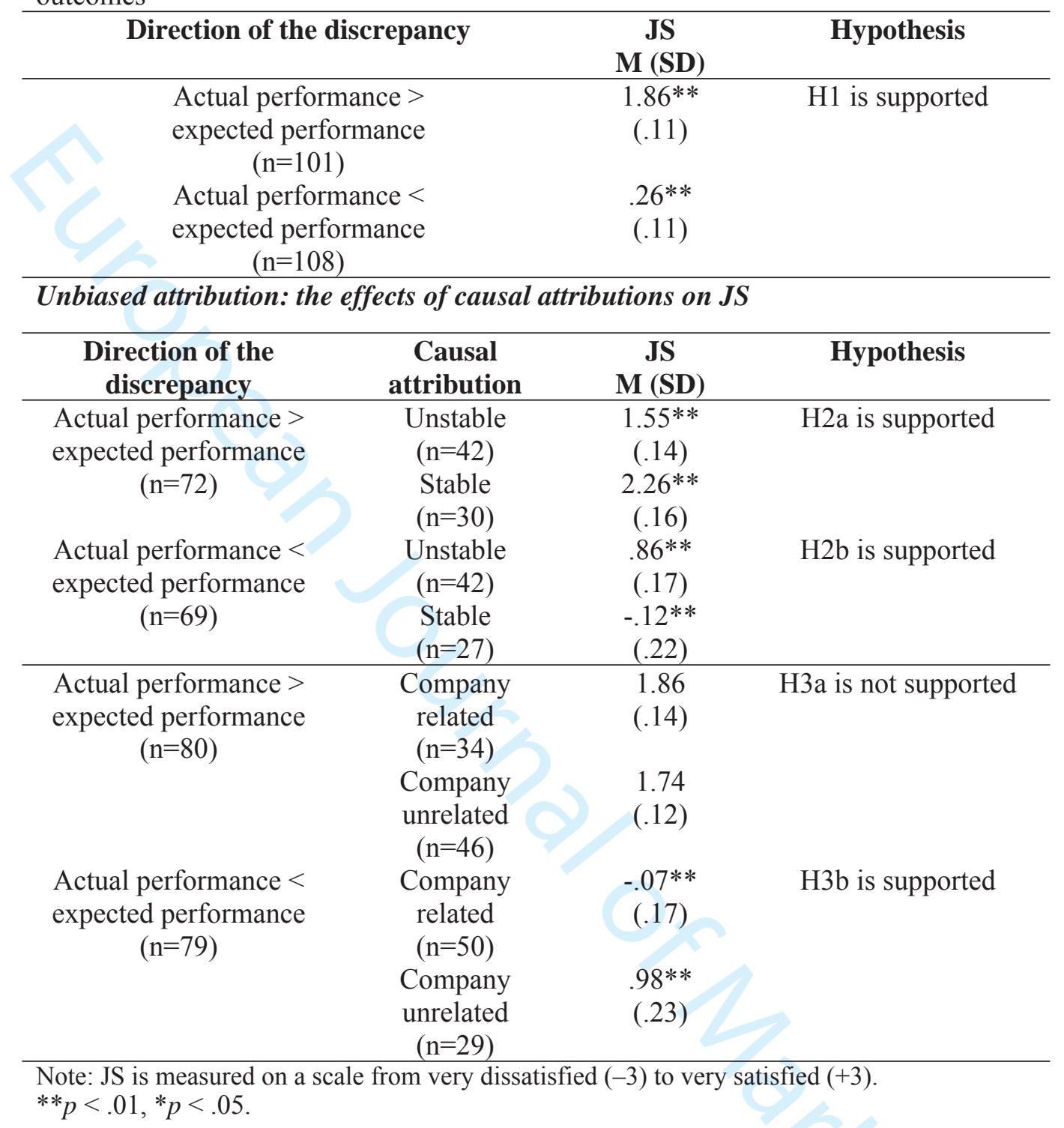


Table V.

Means and standard deviations of job satisfaction (JS) of salespeople with biased and unbiased attributions

\begin{tabular}{|c|c|c|c|c|c|}
\hline $\begin{array}{l}\text { Direction of the } \\
\text { discrepancy }\end{array}$ & $\begin{array}{c}\text { Correct } \\
\text { attribution }\end{array}$ & $\begin{array}{l}\text { Perceived } \\
\text { (reported) } \\
\text { attribution }\end{array}$ & $\begin{array}{c}\text { Attribution } \\
\text { bias }\end{array}$ & $\begin{array}{c}\text { JS } \\
\mathbf{M}(\mathbf{S D})\end{array}$ & Hypothesis \\
\hline \multirow{4}{*}{$\begin{array}{l}\text { Actual performance }> \\
\text { expected performance } \\
\qquad(\mathrm{n}=101)\end{array}$} & $\begin{array}{l}\text { Unstable } \\
(\mathrm{n}=47)\end{array}$ & $\begin{array}{c}\text { Unstable } \\
(\mathrm{n}=42)\end{array}$ & Unbiased & $\begin{array}{l}1.55^{*} \\
(.13)\end{array}$ & \multirow{4}{*}{$\begin{array}{c}\text { H4a is } \\
\text { supported }\end{array}$} \\
\hline & & $\begin{array}{l}\text { Stable } \\
(\mathrm{n}=5)\end{array}$ & Biased & $\begin{array}{c}2.10 * \\
(.38)\end{array}$ & \\
\hline & $\begin{array}{l}\text { Stable } \\
(\mathrm{n}=54)\end{array}$ & $\begin{array}{l}\text { Unstable } \\
(\mathrm{n}=24)\end{array}$ & Biased & $\begin{array}{l}1.85^{*} \\
(.17)\end{array}$ & \\
\hline & & $\begin{array}{l}\text { Stable } \\
(\mathrm{n}=30)\end{array}$ & Unbiased & $\begin{array}{r}2.26^{*} \\
(.15)\end{array}$ & \\
\hline \multirow{4}{*}{$\begin{array}{l}\text { Actual performance }< \\
\text { expected performance } \\
(\mathrm{n}=108)\end{array}$} & $\begin{array}{l}\text { Unstable } \\
(\mathrm{n}=45)\end{array}$ & $\begin{array}{l}\text { Unstable } \\
(\mathrm{n}=3)\end{array}$ & Unbiased & $\begin{array}{c}.86 \\
(.18)\end{array}$ & \multirow{4}{*}{$\begin{array}{l}\text { H4b is not } \\
\text { supported }\end{array}$} \\
\hline & & $\begin{array}{l}\text { Stable } \\
(\mathrm{n}=42)\end{array}$ & Biased & $\begin{array}{l}.83 \\
(.69)\end{array}$ & \\
\hline & $\begin{array}{l}\text { Stable } \\
(n=63)\end{array}$ & $\begin{array}{l}\text { Unstable } \\
(\mathrm{n}=36)\end{array}$ & Biased & $\begin{array}{l}-.22 \\
(.20)\end{array}$ & \\
\hline & & $\begin{array}{l}\text { Stable } \\
(\mathrm{n}=27)\end{array}$ & Unbiased & $\begin{array}{l}-.12 \\
(.23)\end{array}$ & \\
\hline \multirow{4}{*}{$\begin{array}{l}\text { Actual performance }> \\
\text { expected performance } \\
\quad(n=101)\end{array}$} & $\begin{array}{l}\text { Company- } \\
\text { related }\end{array}$ & $\begin{array}{c}\text { Company-related } \\
(\mathrm{n}=34)\end{array}$ & Unbiased & $\begin{array}{l}1.86 \\
(.15)\end{array}$ & \multirow{4}{*}{$\begin{array}{l}\text { H5a is not } \\
\text { supported }\end{array}$} \\
\hline & $(\mathrm{n}=51)$ & $\begin{array}{l}\text { Company-unrelated } \\
(\mathrm{n}=17)\end{array}$ & Biased & $\begin{array}{l}2.18 \\
(.21)\end{array}$ & \\
\hline & $\begin{array}{l}\text { Company- } \\
\text { unrelated }\end{array}$ & $\begin{array}{c}\text { Company-related } \\
(\mathrm{n}=4)\end{array}$ & Biased & $\begin{array}{l}1.81 \\
(.44)\end{array}$ & \\
\hline & $(\mathrm{n}=50)$ & $\begin{array}{c}\text { Company-unrelated } \\
(\mathrm{n}=46)\end{array}$ & Unbiased & $\begin{array}{l}1.75 \\
(.13)\end{array}$ & \\
\hline \multirow{4}{*}{$\begin{array}{l}\text { Actual performance }< \\
\text { expected performance } \\
\quad(n=108)\end{array}$} & $\begin{array}{l}\text { Company- } \\
\text { related }\end{array}$ & $\begin{array}{c}\text { Company-related } \\
(\mathrm{n}=50)\end{array}$ & Unbiased & $\begin{array}{l}-.07^{*} \\
(.17)\end{array}$ & \multirow{4}{*}{$\begin{array}{l}\text { H5b is } \\
\text { supported }\end{array}$} \\
\hline & $(\mathrm{n}=65)$ & $\begin{array}{l}\text { Company-unrelated } \\
(\mathrm{n}=15)\end{array}$ & Biased & $\begin{array}{l}.13^{*} \\
(.32)\end{array}$ & \\
\hline & $\begin{array}{l}\text { Company- } \\
\text { unrelated }\end{array}$ & $\begin{array}{l}\text { Company-related } \\
(\mathrm{n}=14)\end{array}$ & Biased & $\begin{array}{l}.05^{*} \\
(.33)\end{array}$ & \\
\hline & $(\mathrm{n}=43)$ & $\begin{array}{c}\text { Company-unrelated } \\
(\mathrm{n}=29)\end{array}$ & Unbiased & $\begin{array}{l}.98^{*} \\
(.23)\end{array}$ & \\
\hline
\end{tabular}

Note: JS is measured on a scale from very dissatisfied $(-3)$ to very satisfied $(+3)$.

$* * p<.01, * p<.05$. 
Table VI.

Interaction effects on JS (unbiased attribution only)

\begin{tabular}{l|l|l|l|l}
\hline Attribution & df & Mean square & F-value & P-value \\
\hline Actual performance $>$ expected performance & \multicolumn{3}{l}{} \\
Stability & 1 & 3.78 & 5.70 & .02 \\
Company-related attribution & 1 & 0.02 & .03 & .86 \\
Stability $\times$ company-related attribution & 1 & 3.60 & 5.43 & .02 \\
Error & 57 & .66 & & \\
\hline Actual performance < expected performance & 1 & 9.12 & 7.93 & .01 \\
Stability & 1 & 12.17 & 10.58 & .00 \\
Company-related attribution & 1 & 1.68 & 1.46 & .23 \\
Stability $\times$ company-related attribution & 48 & 1.15 & & \\
Error &
\end{tabular}


Figure 1.

Conceptual model of salespeople's performance attributions process and job satisfaction

Hypothesis

explanation

H1

Salespeople's

perceived outcome leads to a general positive or negative emotional reaction to work

\section{H2ab, H3ab}

Causal attributions:

Stable/unstable causes

Company-related/-unrelated causes

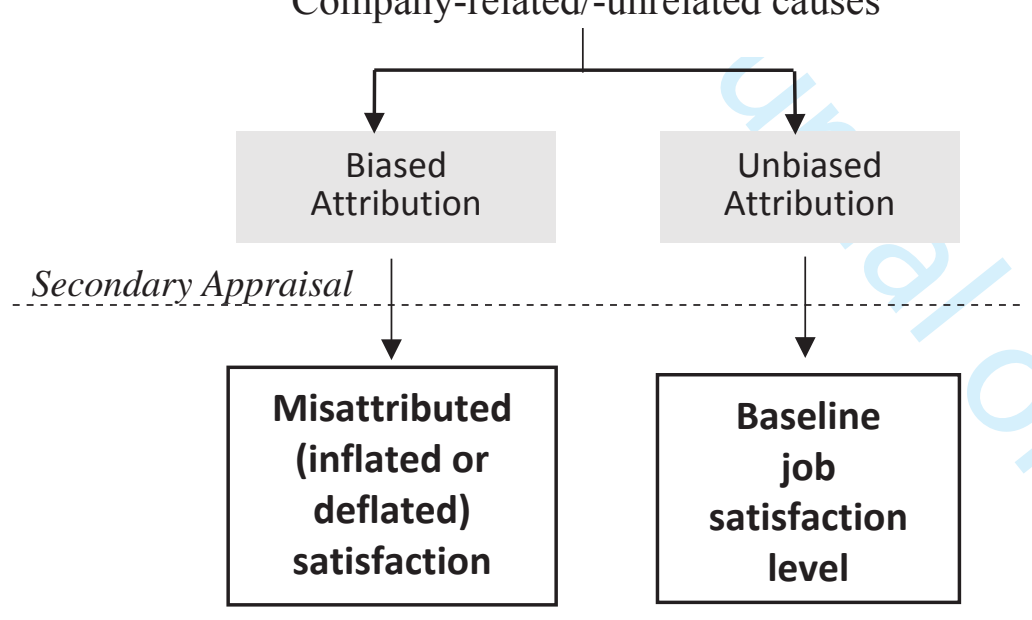

\section{Primary Appraisal}

Salespeople may experience job satisfaction/dissatisfa ction as a result of their causal attributions

\section{H4ab, H5ab}

Salespeople's incorrect attributions may lead to higher (inflated) or lower (deflated) satisfaction than those with correct attributions
Managerial implications

Early
Intervention:

Setting realistic quotas in light of salespeople's expectations
Timely

Intervention:

Correcting attribution biases to obtain "true" and constant satisfaction 
Figure 2.

Impact of attribution bias on job satisfaction

Attribution: causal stability

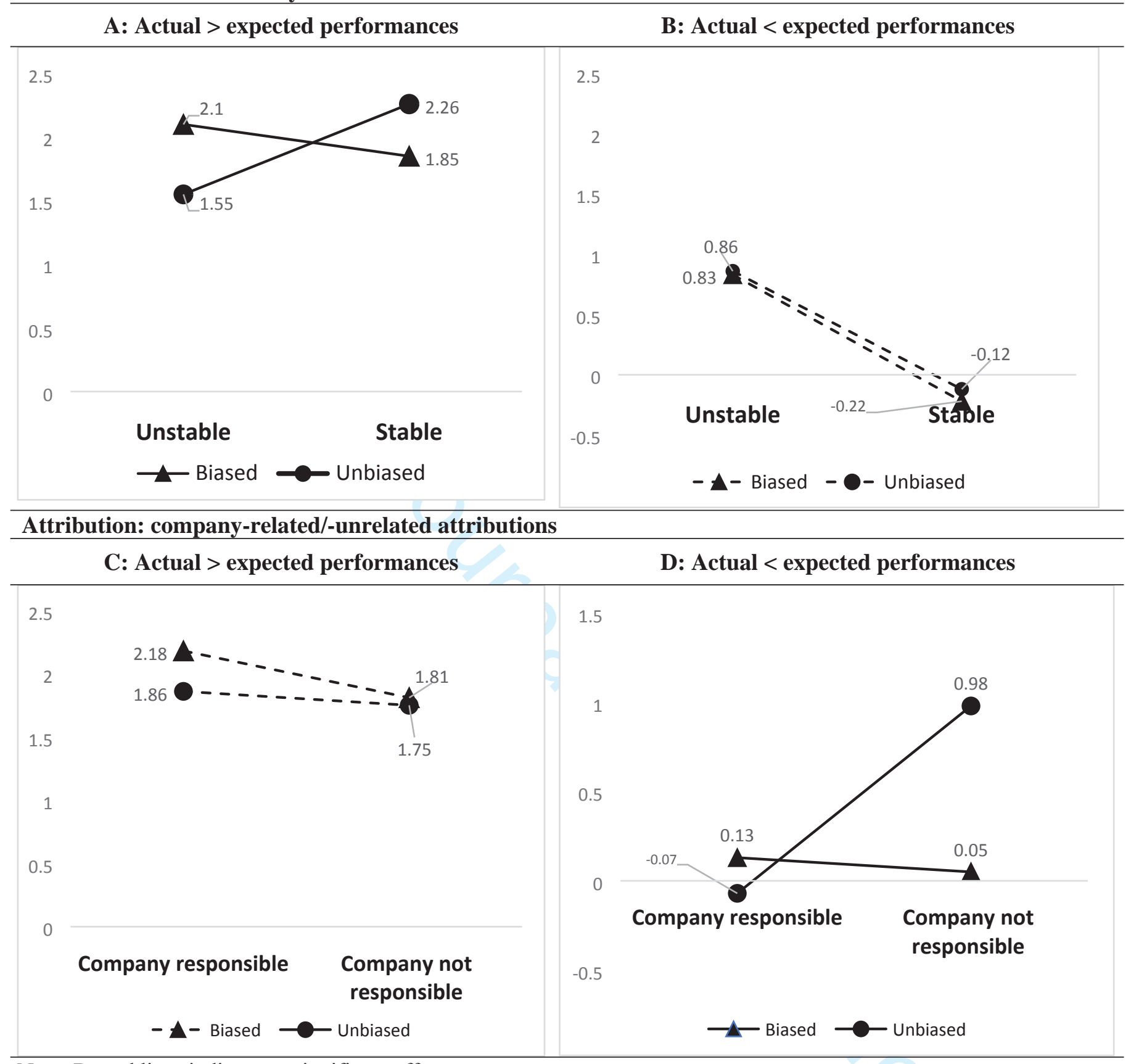

Note: Dotted lines indicate no significant effects. 